\title{
UPAYA MENINGKATKAN AKTIVITAS BELAJAR MATEMATIKA MELALUI MODEL DISCOVERY LEARNING DENGAN THINK-PAIR- SHARE PADA SISWA KELAS VIII.I SMP N 3 KOTO BARU
}

\author{
YENI NOVITRI
}

SMPN 3 Koto Baru, Dharmasraya

Email: yeninovitri75@gmail.com

\begin{abstract}
This is a Classroom Action Reserach in an attemp to improve students' activity in learning Math subject of Grade VIII.1 SMPN 3 Koto Baru on the material of the samenes linear held from September to Desember 2014. The research is formulated in two cycles of twice classroom meetings for each cycle. Every cycle meeting drives four phases; planning, action, observation, and reflection. Instruments applied, are students' activities observation sheets and questionaires. Analysis technique is Qualitative Descriptive and Percentage. The finding result of the reasearch in average is gained improvement to the students' learning activity at every matter or each indicator from cycle one to cycle two; it is from $54 \%$ to $64 \%$.
\end{abstract}

Keywords: Learning Activity, Discovery Learning Model, Think-Pair-Share.

Abstrak: Penelitian ini merupakan Penelitian Tindakan Kelas (PTK) dalam rangka meningkatkan aktivitas belajar matematika kelas VIII.1 SMPN 3 Koto Baru pada materi Persamaan Garis Lurus yang telah dilaksanakan dari bulan September s.d Desember tahun 2014. Penelitian dilakukan dalam dua siklus, masing-masing siklus terdiri dari dua kali pertemuan. Setiap siklus melalui empat tahap yaitu perencanaan , tindakan, observasi dan refleksi. Instrumen yang digunakan dalam penelitian ini terdiri dari lembar observasi aktivitas siswa dan angket. Teknik analisis yang digunakan adalah deskriptif kualitatif dan persentase. Hasil penelitian menunjukkan secara rata-rata aktivitas belajar siswa meningkat dari $54 \%$ menjadi $64 \%$.

Kata kunci: Aktivitas Belajar, Model Discovery Learning,Think-Pair-Share

\section{A. Pendahuluan}

Matematika merupakan salah satu pelajaran yang sangat berperan dalam perkembangan ilmu pengetahuan dan teknologi, Oleh karena itu pemerintah selalu berusaha agar mutu pendidikan matematika semakin baik dari masa ke masa. Usaha tersebut berupa penyempurnaan kurikulum (sekarang dari KTSP menjadi kurikulum 2013), Dengan adanya perubahan kurikulum dari KTSP ke Kurikulum 2013 akan memberi angin segar dalam revolusi pendidikan Indonesia, karena selain diharapkan dapat meningkatkan nilai pengetahuan siswa, juga dapat membentuk sikap siswa yang lebih berkarakter, serta menuntut siswa lebih aktif di kelas dan lebih trampil mengaplikasikan setiap materi pada semua mata pelajaran.

Mendikbud (2014:15) memuat elemen utama perbaikan kurikulum dalam revolusi pembelajaran mencakup: a) lintasan taksonomi Anderson untuk pengetahuan, Dyer untuk ketrampilan, dan Krathwoht untuk sikap, b) pendekatan saintifik, c) inquiri dan discovery, d) project based learning, dan e) cooperative learning. Pada kurikulum 2013 diharapkan pembelajaran tidak lagi berpusat pada guru, dan dituntut siswa yang lebih aktif dalam belajar. Karena dalam kurikulum 2013 ada proses pendekatan saintifik yang memberikan pengalaman belajar dan menuntut keaktifan siswa. 
Menurut Permendikbud no. 81A Tahun 2013 lampiran IV proses pendekatan saintifik terdiri dari lima pengalaman belajar pokok yaitu: mengamati, menanya, mengumpulkan informasi, mengasosiasi dan mengkomunikasikan.

Mendikbud (2014:46) merekomendasikan tiga model pembelajaran pada kurikulum 2013 yang dapat meningkatkan aktivitas belajar siswa, yaitu: 1) Pembelajaran Berbasis Proyek (Project Based Learning/PjBL); 2) Pembelajaran Penemuan (Discovery Learning/DL); 3) Pembelajaran Berbasis Masalah (Problem Based Learning/PBL). Dalam penerapan dikelas dipilih salah satu metode yang cocok dengan materi, dan dipilih juga salah satu strategi pembelajaran cooperatif yang sesuai. Salah satu strategi yang dapat meningkatkan aktivitas belajar siswa adalah model pembelajaran kooperatif tipe Think-Pair-Share ( berpikir, berpasangan dan berbagi).

Pembelajaran kooperatif tipe Think-Pair-Share ( berpikir, berpasangan dan berbagi), diperkirakan akan dapat diterapkan di kelas. Perkiraan ini berdasarkan pada kebiasaan siswa belajar dengan teman, terutama pada teman yang duduk sebangku, maupun teman lainnya. Berdasarkan pengamatan penulis, sering ditemui adanya kecendrungan siswa berdiskusi secara serius dalam pelajaran di kelompok yang terdiri dari dua orang saja. Melalui pembelajaran kooperatif tipe Think-Pair-Share ini, diharapkan siswa sama-sama melakukan proses saintifik, bersama-sama memikirkan, menemukan, menggunakan atau mengkonstruksikan sendiri pengetahuan yang akan mereka peroleh dengan dorongan dari guru. Disamping itu juga mengembangkan potensi siswa secara aktif, mengembangkan semangat kebersamaan pada siswa. Siswa yang pandai biasanya jadi terdorong untuk membantu temannya dalam memecahkan soal yang rumit dengan berdiskusi, sehingga teman yang kurang pandai juga termotivasi untuk menyelesaikan soal-soal. Dengan metode Think-Pair-Share ini siswa juga didorong untuk berani tampil atau berbicara di dalam kelas dan mempertanggung jawabkan kerja mereka.

Pada pelaksanaan Think-Pair-Share, siswa diberi lembaran yang berisi ringkasan materi dan pertanyaan yang menyangkut tentang materi yang akan diajarkan. Lembaran pertanyaan disusun dalam bentuk Lembar Kegiatan Siswa (LKS). LKS diberikan setelah proses mengamati dan materi pelajaran disusun secara sistematis dari pertanyaan yang mudah hingga pertanyaan yang sulit. siswa diberi kesempatan untuk menjawab pertanyaan tersebut semampu mereka dalam batas waktu yang telah ditentukan. Harapan penulis hendaknya melalui pembelajaran kooperatif tipe Think-Pair-Share siswa akan lebih aktif dalam belajar, sehingga suasana belajar menyenangkan dan bermakna. Untuk itu penulis melakukan penelitian tindakan kelas dengan judul "Upaya Meningkatkan Aktivitas Belajar Matematika Melalui Model Discovery Learning dengan Think-Pair-Share Pada Siswa Kelas VIII.I SMPN 3 Koto Baru".

Dari uraian latar belakang dan pembatasan masalah di atas, maka rumusan masalah dalam penelitian ini adalah: Apakah melalui model Discovery Learning dengan Think-Pair-Share dapat meningkatkan aktivitas belajar matematika siswa kelas VIII.1 SMPN 3 Koto Baru? Tujuan penelitian ini adalah untuk melihat aktivitas belajar matematika siswa kelas VIII.1 SMPN 3 Koto Baru jika menggunakan model Discovery Learning dengan Think-Pair-Share. Hasil penelitian ini diharapkan bermanfaat untuk: 1) Siswa, dalam memberikan pengalaman belajar yang lebih aktif, dinamis, kooperatif dan bermakna; 2) Guru, sebagai salah satu alternatif model pembelajaran yang dapat digunakan pada pembelajaran matematika; dan 3) Sekolah, dapat memberikan masukan dan pengembangan dunia pendidikan pada umumnya 
tentang penggunaan strategi pembelajaran untuk menyelenggarakan pembela-jaran yang kreatif dan inovatif sehingga hasil belajar matematika pada khususnya tercapai secara maksimal.

\section{B. Metodologi Penelitian}

Penelitian ini merupakan penelitian tindakan kelas. Pelaksanaannya di kelas VIII.1 SMPN 3 Koto Baru, Kabupaten Dharmasraya yang terletak di Jorong Lubuk Agam, Nagari Ampang Kuranji, dengan jumlah siswa 26 orang yang terdiri dari 10 orang laki-laki dan 16 orang perempuan. Objek penelitian ini adalah pembelajaran matematika dengan materi pembelajaran "Persamaan Garis Lurus"di kelas VIII. SMPN 3 Koto Baru. Waktu yang digunakan dalam penelitian ini selama 3(tiga) bulan, yaitu dari bulan September sampai bulan November 2014 semester I tahun pelajaran 2014/2015. Penelitian ini dilaksanakan dalam dua siklus, masing-masing siklus dua kali pertemuan. Setiap siklus terdiri dari kegiatan perencanaan tindakan, pelaksanaan tindakan, pengamatan tindakan dan refleksi terhadap tindakan. Pengumpulan data dilakukan dengan cara terus menerus pada setiap siklus tindakan. Teknik dan alat pengumpulan data yang digunakan dalam penelitian tindakan kelas ini adalah lembar observasi siswa dan angket. Teknik analisis data yang digunakan adalah Deskriptif Kualitatif dan Persentase.

\section{Hasil dan Pembahasan}

Sesuai dengan rancangan penelitian, pembelajaran dilaksanakan berdasarkan rancangan pembelajaran yang sesuai dengan silabus dan Rencana Pelaksanaan Pembelajaran (RPP). Siklus I dilaksanakan dalam 2 kali pertemuan yaitu pertemuan pertama hari Kamis tanggal 9 Oktober 2014 dan hari Sabtu tanggal 11 Oktober 2014 untuk pertemuan kedua. Pembelajaran yang dilaksanakan adalah meggunakan model Discovery Learning dengan pembelajaran kooperatif tipe Think-Pair-Share dengan menggunakan bantuan Lembar Kerja Siswa (LKS). Siswa dibagi kedalam 13 kelompok yang terdiri dari 2 orang (berpasangan) dengan kemampuan yang berbeda (kelompok atas dan kelompok bawah).

Pengamatan dilakukan terhadap aktivitas saintifik siswa selama pembelajaran yang meliputi 5 tahap yaitu : A1 (Mengamati) : Memperhatikan informasi guru, A2 (Menanya) : Bertanya dan menjawab pertanyaan guru, A3 (Mengolah Informasi) : Membaca LKS dan mempelajari Buku Sumber (proses Think), A4 (Mengasosiasi) : Berdiskusi dengan pasangan mengerjakan LKS (poses Pair), A5 (Mengkomunikasi) : Mengeluar-kan pendapat waktu presentasi ( proses Share). Data hasil pengamatan aktivitas siswa setiap siklus dapat dilihat pada histogram berikut:

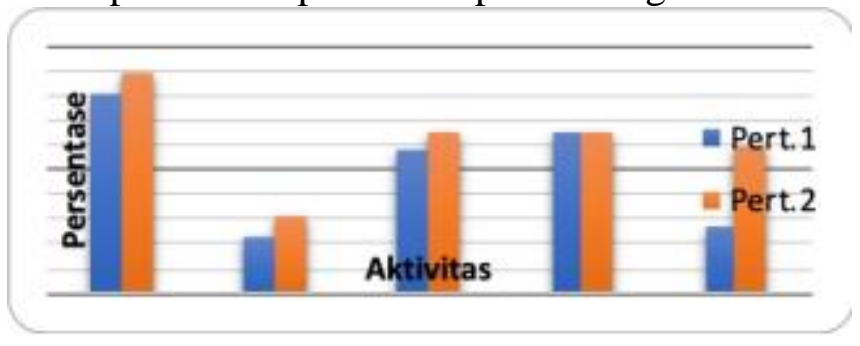

Gambar 1. Histogram aktivitas belajar matematika melalui model Discovery Learning dengan Think-Pair-Share Siklus I 
Dari gambar diatas dapat dirata-ratakan bahwa $\mathrm{A} 1=85 \%$ (banyak sekali), $\mathrm{A} 2=30 \%$ (sedikit sekali), A3=62\% (banyak), A4=65\% (banyak), A5=31\% (sedikit sekali).

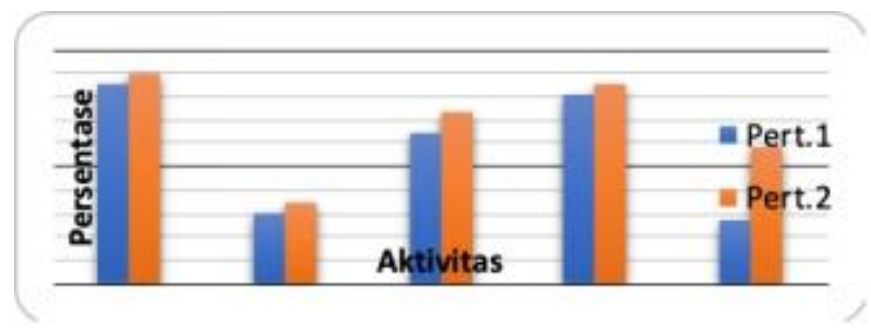

Gambar 2. Histogram Aktivitas Belajar Matematika Melalui Model Discovery Learning dengan Think-Pair-Share Siklus II

Dari gambar diatas dapat dirata-ratakan bahwa $\mathrm{A} 1=87 \%$ (banyak sekali), A2 $=33 \%$ (sedikit sekali), A3=69\% (banyak), A4=83\% (banyak sekali), A5=50\% (sedikit sekali). Hasil angket respon Siswa terhadap model pembelajaran yang diterapkan terlihat pada tabel berikut:

Tabel 1. Hasil angket belajar matematika melalui model Discovery Learning dengan Think-Pair-Share Siklus I

\begin{tabular}{|c|c|c|c|}
\hline NO & PERTANYAAN & YA & TIDAK \\
\hline 1. & $\begin{array}{l}\text { Apakah model Discovery Learning dengan pembelajaran } \\
\text { kooperatif tipe Think-Pair-Share ini kamu senangi? }\end{array}$ & $\begin{array}{c}21 \\
(81 \%)\end{array}$ & $\begin{array}{c}5 \\
(19 \%)\end{array}$ \\
\hline 2. & $\begin{array}{l}\text { Apakah pembelajaran Discovery Learning ini dapat membuat } \\
\text { kamu lebih aktif dalam pembelajaran? }\end{array}$ & $\begin{array}{c}19 \\
(73 \%)\end{array}$ & $\begin{array}{c}7 \\
(27 \%)\end{array}$ \\
\hline 3 & $\begin{array}{l}\text { Apakah dengan pembelajaran Discovery Learning ini } \\
\text { memudahkan kamu memahami pembelajaran? }\end{array}$ & $\begin{array}{c}18 \\
(69 \%)\end{array}$ & $\begin{array}{c}8 \\
(31 \%)\end{array}$ \\
\hline 4 & $\begin{array}{l}\text { Apakah sebelum mengerjakan LKS kamu melakukan proses } \\
\text { berfikir dengan mempelajari buku sumber? }\end{array}$ & $\begin{array}{c}16 \\
(62 \%)\end{array}$ & $\begin{array}{c}10 \\
(38 \%)\end{array}$ \\
\hline 5 & $\begin{array}{l}\text { Apakah dalam mengerjakan LKS kamu bekerja sama teman } \\
\text { pasanganmu? }\end{array}$ & $\begin{array}{c}14 \\
(54 \%)\end{array}$ & $\begin{array}{c}12 \\
(46 \%)\end{array}$ \\
\hline 6 & $\begin{array}{l}\text { Apakah kamu mendapat kesempatan menyampaikan ide dalam } \\
\text { proses belajar berlangsung? }\end{array}$ & $\begin{array}{c}17 \\
(65 \%)\end{array}$ & $\begin{array}{c}9 \\
(35 \%)\end{array}$ \\
\hline 7 & Apakah kamu menyenangi pasangan belajarmu & $\begin{array}{c}15 \\
(58 \%)\end{array}$ & $\begin{array}{c}11 \\
(42 \%)\end{array}$ \\
\hline
\end{tabular}

Tabel 2. Hasil angket belajar matematika melalui model Discovery Learning dengan Think-Pair-Share Siklus II

\begin{tabular}{|c|c|c|c|}
\hline $\mathrm{NO}$ & PERTANYAAN & YA & TIDAK \\
\hline 1. & $\begin{array}{l}\text { Apakah model Discovery Learning dengan pembelajaran } \\
\text { kooperatif tipe Think-Pair-Share ini kamu senangi? }\end{array}$ & $\begin{array}{c}25 \\
(96 \%)\end{array}$ & $\begin{array}{c}1 \\
(4 \%)\end{array}$ \\
\hline 2. & $\begin{array}{l}\text { Apakah pembelajaran Discovery Learning ini dapat membuat } \\
\text { kamu lebih aktif dalam pembelajaran }\end{array}$ & $\begin{array}{c}23 \\
(80 \%)\end{array}$ & $\begin{array}{c}3 \\
(20 \%)\end{array}$ \\
\hline 3 & $\begin{array}{l}\text { Apakah dengan pembelajaran Discovery Learning ini } \\
\text { memudahkan kamu memahami pembelajaran? }\end{array}$ & $\begin{array}{c}24 \\
(92 \%)\end{array}$ & $\begin{array}{c}2 \\
(8 \%)\end{array}$ \\
\hline 4 & $\begin{array}{l}\text { Apakah sebelum mengerjakan LKS kamu melakukan proses } \\
\text { berfikir dengan mempelajari buku sumber? }\end{array}$ & $\begin{array}{c}22 \\
(85 \%)\end{array}$ & $\begin{array}{c}4 \\
(15 \%)\end{array}$ \\
\hline
\end{tabular}




\begin{tabular}{|c|l|c|c|}
\hline 5 & $\begin{array}{l}\text { Apakah dalam mengerjakan LKS kamu bekerja sama teman } \\
\text { pasanganmu? }\end{array}$ & $\begin{array}{c}26 \\
(100 \%)\end{array}$ & $\begin{array}{c}- \\
(0 \%)\end{array}$ \\
\hline 6 & $\begin{array}{l}\text { Apakah kamu mendapat kesempatan menyampaikan ide dalam } \\
\text { proses belajar berlangsung? }\end{array}$ & $\begin{array}{c}17 \\
(65 \%)\end{array}$ & $\begin{array}{c}9 \\
(35 \%)\end{array}$ \\
\hline 7 & Apakah kamu menyenangi pasangan belajarmu & 15 & 11 \\
$(58 \%)$ & $(42 \%)$ \\
\hline
\end{tabular}

Dari hasil angket respon siswa pada siklus I dan siklus II daperoleh: Sikap siswa terhadap pembelajaran dengan menggunakan model Discovery Learning dengan pembelajaran kooperatif tipe Think-Pair-Share semakin baik, siswa sangat menyenangi pembelajaran dengan menggunakan metode ini.

\section{Pembahasan Hasil Penelitian}

Dari pelaksanaan tindakan mulai dari siklus I sampai siklus II didapat kenyataan bahwa model Discovery Learning dengan pembelajaran kooperatif tipe Think-PairShare yang diterapkan dalam proses pembelajaran matematika telah memberikan dampak yang positif terhadap peningkatan aktivitas belajar matematika siswa. Dari data hasil pengamatan aktivitas siswa setiap siklus dapat dilihat pada Tabel 3 berikut :

Tabel 3. Hasil pengamatan aktivitas belajar matematika melalui model Discovery Learning dengan Think-Pair-Share pada Siklus I dan Siklus II

\begin{tabular}{|c|c|c|c|c|}
\hline \multirow[t]{2}{*}{ No } & \multirow{2}{*}{$\begin{array}{l}\text { Proses } \\
\text { Saintifik }\end{array}$} & \multirow[t]{2}{*}{ Aktivitas } & \multicolumn{2}{|c|}{$\begin{array}{c}\text { Rata-rata } \\
\text { Tiap siklus }(\%)\end{array}$} \\
\hline & & & $\mathrm{I}$ & II \\
\hline 1. & Mengamati & Memperhatikan informasi guru & $(85 \%)$ & $(87 \%)$ \\
\hline 2. & Menanya & Bertanya dan menjawab pertanyaan guru & $(30 \%)$ & $(33 \%)$ \\
\hline 3. & $\begin{array}{l}\text { Mengolah } \\
\text { Informasi }\end{array}$ & $\begin{array}{l}\text { Membaca LKS dan mempelajari Buku } \\
\text { Sumber (Saat Think) }\end{array}$ & $(62 \%)$ & $(69 \%)$ \\
\hline 4. & Mengasosiasi & $\begin{array}{l}\text { Berdiskusi dengan pasangan mengerjakan } \\
\text { LKS (Saat Pair) }\end{array}$ & $(65 \%)$ & $(83 \%)$ \\
\hline 5 & $\begin{array}{l}\text { Mengkomuni } \\
\text { ka-sikan }\end{array}$ & $\begin{array}{l}\text { Mengeluarkan pendapat waktu presentasi } \\
\text { akhir (saat Share) }\end{array}$ & $(31 \%)$ & $(50 \%)$ \\
\hline & Rata-rata & & $54 \%$ & $64 \%$ \\
\hline
\end{tabular}

Berdasarkan tabel di atas, persentase aktivitas siswa pada siklus I dan II dapat pula disajikan dalam bentuk grafik berikut : 


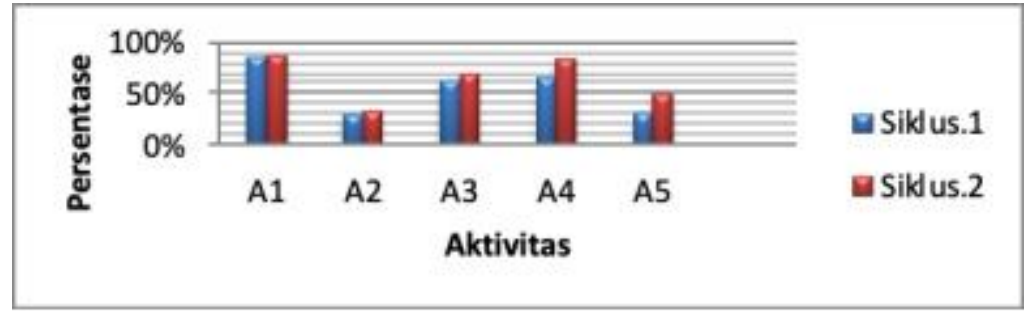

Gambar 3. Histogram aktivitas belajar matematika melalui model Discovery Learning dengan Think-Pair-Share pada Siklus I dan Siklus II

\section{Keterangan :}

A1. Memperhatikan informasi guru

A2. Bertanya dan menjawab pertanyaan guru

A3. Membaca LKS dan mempelajari Buku Sumber (Saat Think)

A4. Berdiskusi dengan pasangan mengerjakan LKS (Saat Pair)

A5. Mengeluarkan pendapat waktu presentasi akhir (saat Share)

Peningkatan aktivitas belajar siswa ini disebabkan karena model Discovery Learning dengan pembelajaran kooperatif tipe Think-Pair-Share merupakan salah satu model pembelajaran yang dapat membantu siswa untuk kreatif dan inovatif untuk memahami konsep pada materi Persamaan Garis Lurus yang telah dirancang dalam Lembar kerja Siswa (LKS). Model Discovery Learning dengan pembelajaran kooperatif tipe Think-Pair-Share ini merupakan suatu cara yang pada dasarnya mampu mendorong terlaksananya aktivitas kelompok guna memantapkan cara berpikir siswa secara individu maupun kelompok dalam pemahaman konsep dan menyelesaikan soalsoal yang diberikan guru. Keunggulan lain seperti berinteraksi dan mengemukakan pendapat juga terasa. Dalam hal ini kerangka kerja siswa dibentuk dalam suatu kerjasama yang melibatkan kemampuan bekerja / belajar bersama untuk menemukan konsep dan memecahkan masalah.

Dalam Model Discovery Learning dengan pembelajaran kooperatif tipe ThinkPair-Share ini siswa diarahkan menemukan konsep dengan bantuan Lembar Kerja Siswa (LKS) melalui kegiatan-kegiatan penyelidikan. Kegiatan penyelidikan dimulai dari pemberian contoh-contoh hingga terbentuk generalisasi, sehingga siswa termotivasi untuk memahaminya lebih jauh dan memacu siswa untuk berfikir kritis. Penemuan konsep dan prinsip yang dilakukan siswa melibatkan proses mental dalam mencari hubungan-hubungan, membuat dugaan sehingga pengetahuan yang didapat sangat kukuh dan mendalam karena siswa sendiri yang menemukan konsepnya.

Proses penemuan konsep dilakukan secara berkelompok (berpasangan), siswa memiliki tanggung jawab secara individu dan kelompok dan memiliki kesempatan yang sama untuk berhasil. Siswa yang memiliki kemampuan matematika lebih tinggi dapat membantu siswa (pasangannya) yang kemampuannya lebih rendah dalam belajar matematika.

\section{Penutup}

Setelah dilakukan penelitian tindakan kelas, maka berdasarkan hasil observasi dan hasil refleksi dapat disimpulkan bahwa: 1) Model Pembelajaran Discovery Learning dengan Think-Pair-Share dapat meningkatkan aktivitas belajar matematika siswa kelas VIII SMPN 3 Koto Baru Kabupaten Dharmasraya; 2) Peningkatan aktivitas belajar matematika siswa kelas VIII SMPN 3 Koto Baru Kabupaten 
Dharmasraya dengan menerapkan model pembelajaran ini dari siklus I ke siklus II adalah 54\% menjadi 64\%. Berdasarkan kesimpulan maka dapat dikemukakan beberapa saran demi perbaikan dan peningkatan kualitas pembelajaran matematika sebagai berikut: 1) Bagi siswa yang terlibat dalam penelitian ini agar tetap menanamkan sikap positif dalam pembelajaran matematika yaitu aktif, menjalin kerjasama yang baik, menghargai pendapat orang lain dan bersemangat dalam belajar. 2) Bagi guru matematika, model pembelajaran Discovery Learning dengan ThinkPair-Share dapat dijadikan sebagai alternatif untuk meningkatkan aktivitas belajar matematika siswa.

\section{Daftar Pustaka}

Asma, Nur. (2009). Model Pembelajaran Kooperatif. Padang: UNP

Lie, Anita. (2002). Cooperative learning. Jakarta : Grasindo.

Mendikbud (2014). Materi Pelatihan Implementasi kurikulum 2013. Jakarta : PSDMPK-PMP

Muliyardi. (2002). strategi pembelajaran matematika. Padang : FMIPA Frank Lyman

Nurhadi, dkk. (2004). Pembelajaran Kontekstual (Contekstual Teaching and Learning/CTL) dan penerapannya dalam KBK. Malang : Univ Negeri Malang

Silberman, M. (2007).Active Learning 101 Strategi Pembelajaran.Yogyakarta : Pustaka Intan Madani. 